\title{
Characterization of a New Lignocellulosic Fiber from Brazil: Imperata brasiliensis (Brazilian Satintail) as an Alternative Source for Nanocellulose Extraction
}

Kelly Cristina Coelho de Carvalho Benini, Herman Jacobus Cornelis Voorwald, Maria Odila Hilário Cioffi, Andressa Cecília Milanese \& Heitor L. Ornaghi Jr.

To cite this article: Kelly Cristina Coelho de Carvalho Benini, Herman Jacobus Cornelis Voorwald, Maria Odila Hilário Cioffi, Andressa Cecília Milanese \& Heitor L. Ornaghi Jr. (2017) Characterization of a New Lignocellulosic Fiber from Brazil: Imperata brasiliensis (Brazilian Satintail) as an Alternative Source for Nanocellulose Extraction, Journal of Natural Fibers, 14:1, 112-125, DOI: $10.1080 / 15440478.2016 .1167647$

To link to this article: https://doi.org/10.1080/15440478.2016.1167647

曲 Published online: 04 Oct 2016.

щ Article views: 141

View Crossmark data $₫$
Submit your article to this journal $ک \pi$

View related articles $\llbracket$

Citing articles: 5 View citing articles $\widetilde{ }$ 


\title{
Characterization of a New Lignocellulosic Fiber from Brazil: Imperata brasiliensis (Brazilian Satintail) as an Alternative Source for Nanocellulose Extraction
}

\author{
Kelly Cristina Coelho de Carvalho Benini (10 ${ }^{a}$, Herman Jacobus Cornelis Voorwalda, \\ Maria Odila Hilário Cioffia, Andressa Cecília Milanese ${ }^{b}$, and Heitor L. Ornaghi, Jr. ${ }^{c}$ \\ aFatigue and Aeronautical Materials Research Group, Department of Materials and Technology, UNESP-Univ. \\ Estadual Paulista, Guaratinguetá, São Paulo, Brazil; 'batigue and Aeronautical Materials Research Group, \\ Department of Civil Engineering, UNESP_Univ. Estadual Paulista, Guaratinguetá, São Paulo, Brazil; \\ 'Engineering and Materials Science Graduate Program (PGMAT), Univ. Caxias do Sul, Caxias do Sul, RS, Brazil
}

\begin{abstract}
The chemical, physical and thermal properties of a new lignocellulosic fiber from Brazil (Imperata brasiliensis) were examined by SEM, chemical composition, XRD, FTIR, and TGA. Fibers were analyzed aiming to compare the properties of its new natural resource with other lignocellulosic fibers used as a source of nanocellulose extraction. Microscopy analysis demonstrated that the bundle of fibers presented a variety of size and shapes, ranging between 25 and $500 \mu \mathrm{m}$, while a single fiber has a diameter of 5 $\mu \mathrm{m}$. The chemical composition showed the presence of $37.7 \%$ of cellulose, $35 \%$ of hemicellulose and $14.3 \%$ of lignin. The total crystallinity index $(\mathrm{Cl})$ calculated using Segal method was of $36.6 \%$. By TGA, it was possible to identify the degradation step of each primary component of lignocellulosic fiber and to observe that the onset degradation temperature was $157^{\circ} \mathrm{C}$. With the results of ATR-FTIR technique, it was possible to estimate the $\mathrm{Cl}$, and the results exhibited good agreement with that calculated by XRD. Finally it was possible to conclude that fibers obtained from Imperata brasiliensis are suitable to be used as a resource for nanocellulose obtainment since presents almost the same properties of other lignocellulosic fibers successfully used in literature for nanocellulose extraction.
\end{abstract}

\section{摘要}

在本研究中, 用 SEM、化学组成、X射线衍射、红外光谱和 TGA 等方法检 查一种来自巴西的新木质纤维素纤维 (巴西白茅) 的化学、物理和热性

质。研究分析旨在将其新型天然资源的性质与作为纳米纤维素提取源的木 质纤维素纤维进行比较。显微镜分析表明, 纤维束呈现多种尺寸和形状, 范围在 25 和 500 微米之间, 而单纤维的直径为 5 微米。化学组成显示纤维 素占 $37.7 \%$, 半纤维素占 $35 \%$, 木质素占 $14.3 \%$ 。使用西格尔方法计算的 总结晶度指数 $(\mathrm{CI})$ 为 $36.6 \%$ 。根据TGA, 可以确定木质纤维素纤维的每个 主成分的降解步骤, 且观测到的发作降解温度为 $157^{\circ} \mathrm{C}$ 。使用 ATR-FTIR 技 术的结果, 可以估计 $\mathrm{Cl}$, 其结果与通过 XRD 的计算结果相当吻合。最后, 可以得出结论, 从巴西白茅提取的纤维适于用作纳米纤维素的获得来源, 因为其中纤维的性质与文献中用来成功提取纳米纤维素的其他木质纤维素 几乎完全相同。

\section{KEYWORDS}

ATR-FTIR; Brazilian satintail; Imperata brasiliensis fibers; microscopy analysis; thermal analysis; X-ray analysis

\section{关键词}

巴西白茅根; 巴西白茅纤 维; 显微镜分析; 热分析; 射线分析

CONTACT Kelly Cristina Coelho de Carvalho Benini kcccarvalho@hotmail.com U UNESP_Univ. Estadual Paulista, Guaratinguetá, Brazil.

Color versions of one or more of the figures in the article can be found online at www.tandfonline.com/wjnf. 


\section{Introduction}

Cellulose and nanocellulose fibers can be extracted from different lignocellulosic sources such as wood and agricultural residues. The characterization of cellulose microfibrils and/or cellulose whiskers from natural sources, such as wood (Abe and Yano 2009; Chen et al. 2011), bamboo (Chen et al. 2011), sisal (Belbekhouche et al. 2011), cotton (Teixeira et al. 2010), rice straw (Abe and Yano 2009), potato (Abe and Yano 2009), hemp (Karimi et al. 2014), and coconut shell (Abraham et al. 2013), among others, are reported in the literature.

According to Chen et al. (2011), a wide variety of plant species are available, and the primary differences among these plants are the tissue structure and chemical function. The properties are mainly influenced by cellulose, hemicellulose and lignin contents. Usually higher crystalline cellulose fiber is used in applications that require higher tensile strength as cotton (John and Thomas 2008). Hemicellulose is the most responsible by the moisture content and thermal degradation behavior (Beg and Pickering 2008; Methacanon et al. 2010) meanwhile lignin is the main responsible for the char produced in the pyrolysis extending over the entire degradation temperature range (Romanzini et al. 2012). Other fiber components that can be mentioned are pectin and waxes. The former gives plants flexibility and waxes consist of different types of alcohols (John and Thomas 2008). Thus the isolation and characterization of nanofibers from different plants is necessary to make a comparison and an efficient exploitation of these resources.

In the special case of nanofibers, one of the main factors to be studied is the hydrogen bonds intensity between the individualsnanofibrils. The hemicellulose and lignin content are also relevant due to hemicellulose can also act as a binder between the individual nanofibrils and hinder the isolation (Poletto, Zattera, and Santana 2012; Poletto et al. 2012).

Among the various lignocellulosic sources that can be exploited to obtain nanocellulose, a plant not yet widely studied for this purpose is the ImperatabrasiliensisTrin. (Brazilian Satintail), Figure 1. The plant is considered a weed that can be found in degraded pastures and grown in different regions of Brazil, such as the South, Southeast, Northeast and Midwest (Carvalho et al. 2000).

Brazilian satintail is a common designation of a gramineae specimen, the scientific name of which is ImperataBrasiliensisTrin (IB). IB is a perennial plant that currently has no industrial application and is still only being used in its dried form for making roofs of palapas on the Brazil coastal region (Souza et al. 1985). This gramineae is a monocotyledon, which belongs to the group of angiosperm plants in the Liliopsida class, Commelinidae subclass and botanical family of Poaceae(USDA 2014). This plant is native to southern North America, Central America, and South America, extending from the Cape Region of Baja California Sur, Mexico southward to Brazil and Argentina. The IB has leaves, mostly basal and approximately 5-13 $\mathrm{mm}$ wide with erect culms from 36-74 cm tall (Howard 2005).

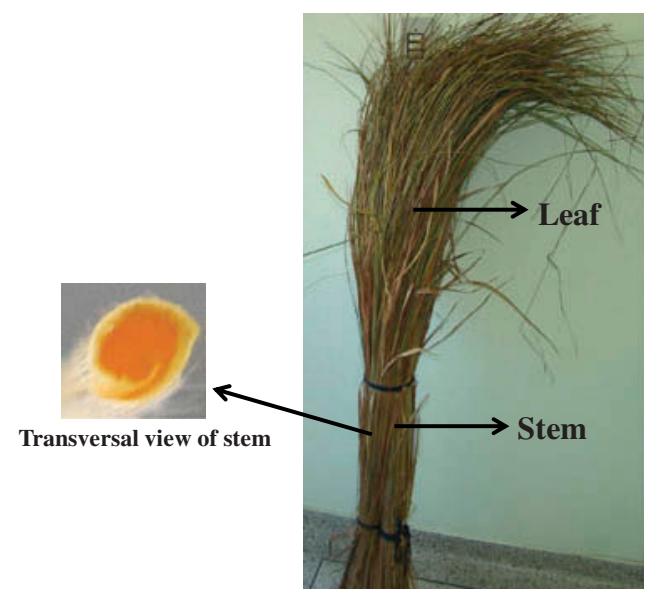

Figure 1. Imperata brasiliensis plant with the indication of leaf, stem, and transversal view of a unit stem. 
The use of these fibers, in micrometric scale, as a reinforcement for thermoplastic composites were previously reported by our research group (Machado et al. 2009; Mulinari et al. 2009), although the properties and characteristics of these lignocellulosic fibers, as well as its use as a cellulose source in the process of nanocellulose extraction, were not found in prior studies.

In the present work fibers extracted from Brazilian Satintail plant were examined by SEM, chemical composition, XRD, FTIR and TGA and its properties were compared with it of other lignocellulosic fibers to determined the use viability of these fibers as a cellulose source for future obtention of nanocellulose.

\section{Experimental}

\section{Extraction fibers procedure}

The IB plant was collected from farms in the Guaratinguetá at São Paulo state, Brazil (latitude $-22^{\circ} 49^{\prime} 0 \mathrm{~S}$ and longitude $-45^{\circ} 13^{\prime} 0 \mathrm{~W}$ ). The city is located at 530 metres above sea level, tropical climate. The stems and the leaves of the plant were analyzed.

Approximately $5 \mathrm{~cm}$ of the crown were taken out of the plant, and the stems and the leaves were subsequently ground, sieved until 25 mesh and, dried in an oven at $60^{\circ} \mathrm{C}$ for $48 \mathrm{~h}$ to remove all the moisture content, as indicated in Figure 2.

\section{Scanning electron microscopy (SEM)}

The morphology of IB fibers was analyzed with a JEOL JSM5310 scanning electron microscope with a tungsten filament operating at $20 \mathrm{kV}$, utilizing a low vacuum technique and working distance of $12 \mathrm{~mm}$. All samples were coated with gold to make them conductive before the SEM analysis.

\section{Real and apparent density}

The real density ( $\rho r)$, were measured using a Real Density Analyzer (Helium Picnometer), Quantachrome Instruments (UltraFoam 1200e model), under helium gas flow. Five measurements for each sample were conducted at $24.4^{\circ} \mathrm{C}$.

The apparent density ( $\rho$ a) was determined using the Archimedes method, based on ASTM D3800 M, using hexane as a non polar solvent and calculated according to Eq. (1):

$$
\rho a=\left(\rho_{\text {hexane }} W f_{\text {air }}\right) /\left(W f_{\text {air }}-W f_{\text {hexane }}\right)
$$

where $\rho_{\text {hexane }}$ is the hexane density $\left(0.6690 \pm 0.011 \mathrm{~g} / \mathrm{cm}^{3}\right)$ and $\mathrm{Wf}_{\text {air }}$ and $\mathrm{Wf}_{\text {hexane }}$ are the fiber weight in air and hexane, respectively.

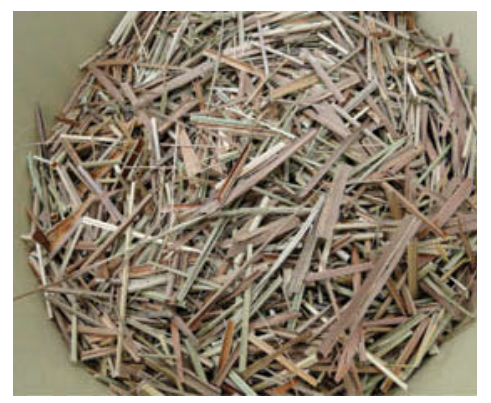

(a)

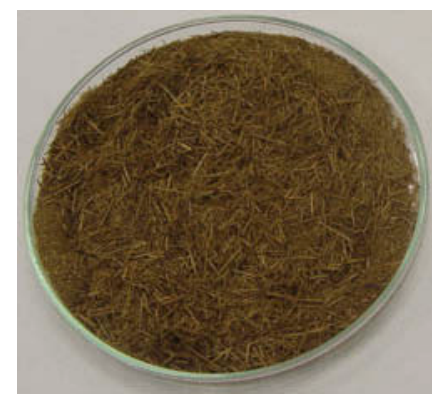

(b)

Figure 2. Imperata brasiliensis fibers (a) grounded stems and leaves and (b) sieved fibers after dried. 


\section{Chemical composition}

The percentual amount of total lignin, holocellulose (cellulose + hemicellulose) and extractives for IB fibers were determined according to ABCP M 3/69 standard. Briefly, the amount of soluble lignin in sulfuric acid was obtained by measuring the UV- vis absorption of the acid filtrate from the determination of the Klason lignin (insoluble) into mini-samples. The holocellulose content was obtained from the extraction with glacial acetic acid, sodium acetate and sodium chlorite solution and the final amount of holocellulose content was obtained according to the equation (2).

$$
\text { \%holocellulose }=\frac{100 x P_{\text {holocellulose }}}{P_{\text {pulp }}}
$$

where $\mathrm{P}_{\text {holocellulose }}$ is de weight of holocellulose $(\mathrm{g})$ and $\mathrm{P}_{\text {pulp }}$ is the weight of the pulp.

For the determination of extractives content it was used soxhlet extraction with alcohol-toluene, alcohol and hot water successively.The cellulose content was estimated using the density method developed by Mwaikambo and Ansell (2001) and applied by Fiore et al. (2014), which calculate the cellulose content, with the measure of real and apparent densities, according to Eq. (3).

$$
\% \text { cellulose }=\left[2\left(\frac{\rho_{a}}{\rho_{r}}+\frac{\rho_{r}}{\rho_{\text {cellulose }}}\right)-\frac{\rho_{a}}{\rho_{\text {cellulose }}}-2\right] \bullet 100
$$

where $\rho_{\text {cellulose }}$ is the density of cellulose $\left(\rho_{\text {cellulose }}=1.592 \mathrm{~g} / \mathrm{cm}^{3}\right.$ ) (Fioreet al. 2014), $\rho_{a}$ is the apparent density and $\rho_{r}$ is the real density.

\section{X-ray diffraction (XRD)}

The diffractograms were recorded on a Shimadzu diffractometer (XDR-6000model), operating at $40 \mathrm{kV}, 30$ $\mathrm{mA}$ and $\mathrm{CuKa}$ radiation $(\lambda=0.1542 \mathrm{~nm})$. The intensities were measured in the $10<2 \theta<50^{\circ}(5 \mathrm{~s} / \mathrm{step})$. The crystallinity index (CI) was calculated using the empirical method (French 2013; Segal et al. 1959), Eq. (4):

$$
C I=\frac{I_{(200)}-I_{(a m)}}{I_{(200)}} \times 100
$$

where $I_{(200)}$ is the maximum intensity of the diffraction peak from the (200) plane at $2 \theta \approx 22^{\circ}$ and $\mathrm{I}_{(\mathrm{am})}$ is the intensity of the minimum intensity between the major peaks.

The values of $\mathrm{d}$-spacing and the crystallite size perpendicular to the plane $(L)$ for different crystalline planes were calculated.

The $d$-spacing of each plane was calculated using Bragg's equation (Ornaghi Jr. et al. 2014a) and the crystallite size was calculated using the Scherrer equation (Eq. (5)):

$$
L=(0.94 \lambda) /(H \cos \theta)
$$

where $L$ is the crystallite size perpendicular to the plane, $\lambda$ is the X-ray wavelength $(0.1542 \mathrm{~nm}), H$ is the full-width at half-maximum in radians, and $\theta$ is the Bragg angle.

\section{Fourier transform infrared (FTIR) spectroscopy}

To evaluate the functional groups presented in the surface of the fibers the ATR (Attenuated Total Reflection) technique was used. The spectra of fibers was determined in a Spectrun GX Perkin Elmer spectrophotometer, by taking 8 scans, in the range of $4000-400 \mathrm{~cm}^{-1}$ with a resolution of $4 \mathrm{~cm}^{-1}$. 


\section{Thermogravimetric analysis (TGA)}

The samples of IB fibers were analyzed with a TG/DTG SII Nanotechnology INC (6200 model), with a heating rate of $10^{\circ} \mathrm{C} \mathrm{min}{ }^{-1}$ under nitrogen flow of $60 \mathrm{~mL} / \mathrm{min}$, yielding a temperature ranging of $25^{\circ} \mathrm{C}$ to $550^{\circ} \mathrm{C}$, using approximately $10 \mathrm{mg}$ of sample. The onset temperature of degradation was determined from the first inflection of the baseline in the DTG curve, according to ASTM E2550.

\section{Results and discussion}

\section{Scanning electron microscopy analysis}

Figure 3 shows the surface morphology SEM images of IB fibers. It was possible to observe the bundle of fibers present in a range of size and shapes, because stems and leaves were analyzed together. Some fibers appear as elongated and flattened shapes; others are more cylindrical and have smaller diameters. Additionally, there is the presence of released particles scattered on the surface of them, as indicated in Figure $3 \mathrm{a}$.

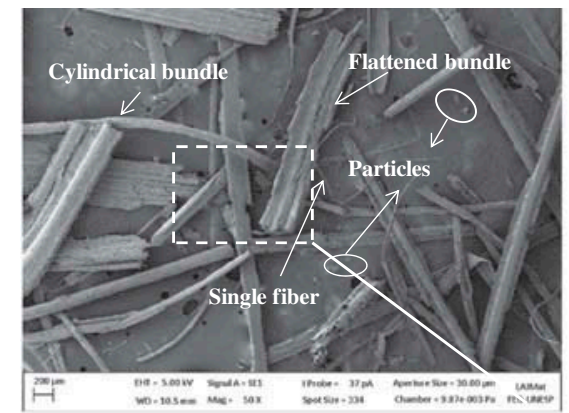

(a)

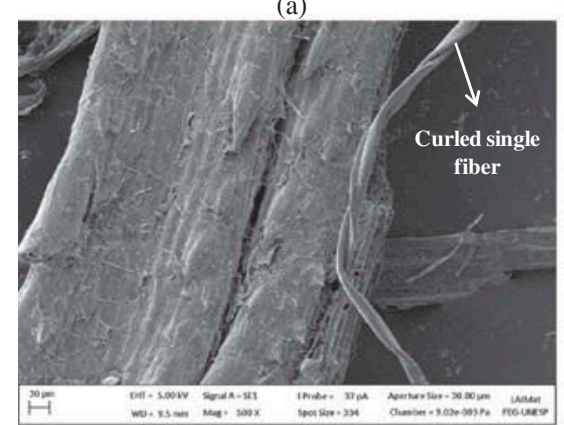

(c)

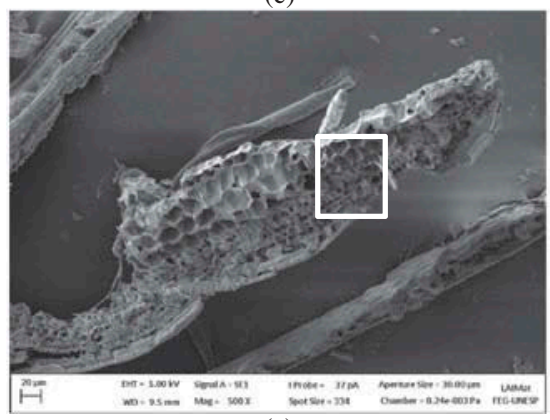

(e)

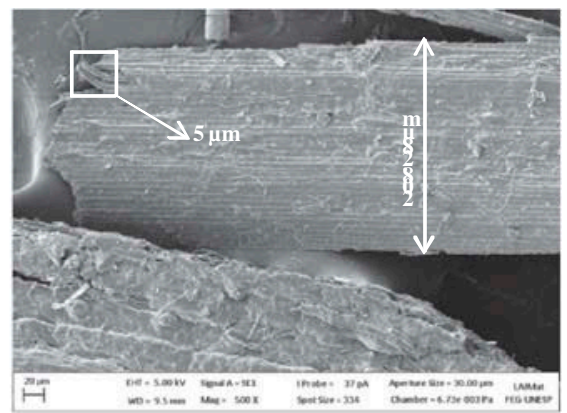

(b)

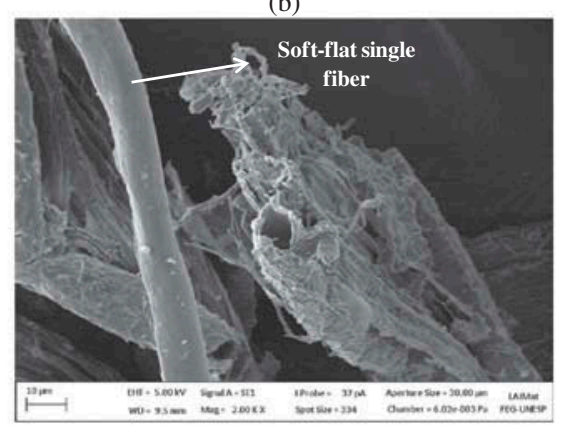

(d)

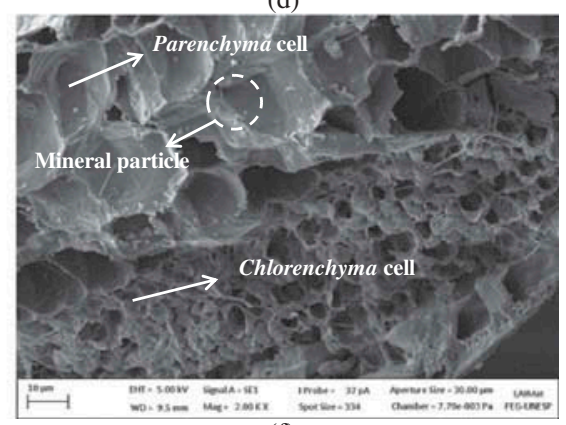

(f)

Figure 3. SEM of IB fibers: (a) presence of flattened and cylindrical bundles as well particles on the surface of the fiber; (b) dimensions of the bundle and single fiber; $(c)$ presence of a curled single fiber; (d) presence of a soft-flat single fiber; (e) inner fiber surface and ( $f$ ) details of parenchyma and chlorenchyma cells. 
In Figure $3 b$ it was possible to observe that each fiber bundle is formed by a set of small diameter fibers, which are coated with a surface layer consisting of waxes and extractives (Kargarzadeh et al. 2012). Bundle diameters range between 25 to $500 \mu \mathrm{m}$, while a single fiber has diameter of approximately $5 \mu \mathrm{m}$. Single fibers are arranged in a parallel way, which is characteristic of secondary wall of the plants, layers $\mathrm{S} 1$ or $\mathrm{S} 3$, as observed by Bilba, Arsene, and Ouensanga (2007) in the SEM analysis of banana-trees core fibers.

Some single fibers, with an average diameter of $15 \mu \mathrm{m}$, presented curled (Figure 3c) and soft-flat (Figure 3d) shape, as observed for velvet leaf (Reddy and Yang 2008) and linter (Morais et al. 2013) fibers.

According to Morais et al. (2013) this curled shape increases the surface area and makes the fiber more reactive than typical cotton fibers. On the other hand, the flat shape increases its specific area and favors chemical reactions such as acidic hydrolysis, the most chemical process used by the extraction of nanocellulose.

In addition, Reddy and Yang (2008) reported that curly shape also should provide better cohesiveness between the single cells as well as increase the strength of the fibers.

The inner fiber surface reveals the presence of parenchyma and chlorenchyma cells, as observed in Figure $3 e$ and 3f, where they are presented in the cell wall of plant fibers. Figure $3 \mathrm{f}$ also shows the presence of some mineral particles. The diameter of the parenchyma cell is in the range of 15-25 $\mu \mathrm{m}$. The same morphology was observed for other lignocellulosic fibers used as a source of nanocellulose extraction, such as Syngonanthusnitens (Capim Dourado) and potato tuber cells in the work of Siqueira et al. (2010) and Dufresne (2000), respectively.

\section{Chemical composition and physical properties}

The chemical composition of fibers is extremely important in the characterization of new sources of cellulose because affects mechanical properties, fire resistance, resilience and biodegradability (Indran et al. 2014). The knowledge of each fiber component, as well as their proportion, facilitates the selection of the adequate pre-treatment (chemical or mechanical) for removal of the amorphous and non-cellulosic materials not suitable for obtention of cellulose and nanocellulose fibers.

The cellulose, hemicellulose, total lignin and extractives contained in IB fibers were determined and results are shown in Table 1 . These values were compared to those previously reported in the literature for other lignocellulosic fibers used as a source of nanocellulose fibers.

From the $72.7 \%$ of holocellulose obtained by chemical analysis for IB fibers, it was possible to theoretically estimate $37.7 \%$ of the holocellulose being comprised of cellulose. The cellulose content was estimated and calculated using the relation between real and apparent density in Eq. (3).

Considering the cellulose content shown in Table 1, it was possible to conclude that IB fibers, extracted from stems and leaves presented almost the same amount of cellulose content as other lignocellulosic fibers successfully used in the literature as a source of nanocellulose. Such examples include wheat straw, garlic skin, empty fruit bunches of oil palm, menkuang leaves and branch-barks of mulberry.

Table 1. Properties of IB fibers in comparison with other lignocellulosic fibers.

\begin{tabular}{lcccccc}
\hline & \multicolumn{5}{c}{ Chemical Composition } & \\
\cline { 2 - 5 } Fiber & $\begin{array}{c}\text { Cellulose } \\
\text { (wt\%) }\end{array}$ & $\begin{array}{c}\text { Hemicellulose } \\
\text { (wt\%) }\end{array}$ & $\begin{array}{c}\text { Lignin } \\
\text { (wt\%) }\end{array}$ & $\begin{array}{c}\text { Extractives } \\
\text { (wt\%) }\end{array}$ & IC (\%) & Ref. \\
\hline Imperata brasiliensis (Satintail) & $37.7^{*}$ & 35.0 & 14.3 & 13.8 & 36.6 & This study \\
Wheat straw & 43.2 & 34.1 & 22.0 & - & 57.5 & Alemdar and Sain 2008 \\
Garlic skin & 41.7 & 20.8 & 34.5 & 3.0 & 35.0 & Reddy and Rhim 2014 \\
Empty fruit bunches of oil palm & 40.0 & 23.0 & 21.0 & 2.0 & 40.0 & Jonoobi et al. 2011 \\
Pandanus Tectorius (Mengkuang leaves) & 37.3 & 34.4 & 24.0 & 2.5 & 55.1 & Sheltami et al. (2012) \\
Morus alba L. (Branch-barks of mulberry) & 37.4 & 25.3 & 9.9 & - & 46.9 & Li et al. (2009) \\
Kenaf bast & 61.2 & 18.5 & 12.9 & - & 62.9 & Karimi et al. (2014) \\
Syngonanthus nitens (Capim Dourado) & 67.0 & 23.0 & 6.5 & - & 70.1 & Siqueira et al. (2010) \\
\hline
\end{tabular}

* estimated value. 
On the other hand, the lignin content obtained was lower than wheat straw, garlic skin, empty fruit bunches of oil palm and menkuang leaves. The lower amount of lignin is an interesting finding because this chemical component acts as a binder between the fibril elements and its presence hinders access of acid to the cellulose amorphous domains during the process of obtaining nanofibers by acid hydrolysis (Lee, Hamid, and Zain 2014; Marino et al. 2015; Ng et al. 2015; Pereira et al. 2015).

The accessibility of cellulose is also affected by hemicellulose, since cellulose fibrils are coated by hemicellulose branches with short lateral chain (pentoses, hexoses and acetylated sugars). However, hemicellulose, during the high-temperature alkali treatment, a common pre-chemical treatment used before the acid hydrolysis for nanocellulose obtention, is partially hydrolyzed and become water soluble (Kargarzadeh et al. 2012; Lee, Hamid, and Zain 2014; Silva et al. 1998).

On the other hand, lignin,due to its complex chemical structure, becomes more difficult to be removed during the pre-chemical treatments stage and other chemical treatments, such as bleaching, should be applied to the fiber, adding cost for the nanocellulose extraction process (Pereira et al. 2015; Ng et al. 2015).

\section{Thermogravimetric analysis}

The thermal stability of IB fibers were investigated by thermogravimetry and results are shown in Figure 4 and Table 2. It is important to highlight that in the study of nanocellulose extraction viability from lignocellulosic fibers, the TGA supports the results obtained in the chemical composition analysis, since hemicellulose, cellulose and lignin usually decompose themselves at different temperatures due to its chemical structures (Morán et al. 2008).

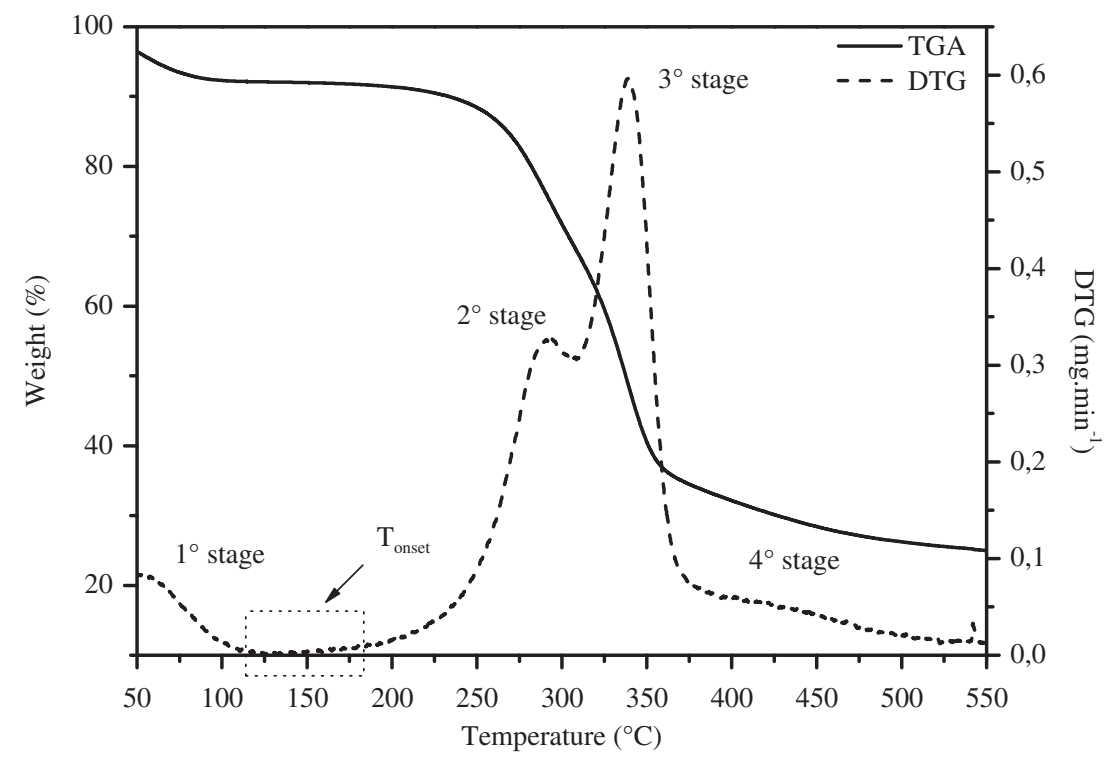

Figure 4. TGA and DTG curves of IB fibers.

Table 2. Weight loss and degradation temperature of IB fibers.

\begin{tabular}{lccccc}
\hline Degradation stages & $\Delta T\left({ }^{\circ} \mathrm{C}\right)$ & $T_{\text {peak }}\left({ }^{\circ} \mathrm{C}\right)$ & $T_{\text {onset }}\left({ }^{\circ} \mathrm{C}\right)$ & Weight loss $(\%)$ & Residue at $550^{\circ} \mathrm{C}(\%)$ \\
\hline $1^{\circ}$ & $25-125$ & 55 & 157 & 7.9 & 25.0 \\
$2^{\circ}$ & $150-310$ & 292 & & 24.7 & \\
$3^{\circ}$ & $310-375$ & 339 & & 32.8 & \\
$4^{\circ}$ & $375-550$ & 400 & & 9.5 & \\
\hline
\end{tabular}


The analyzed fibers present four distinct stages, which are better observed in the DTG curve.The first stage (until $125^{\circ} \mathrm{C}$ ) is due to the vaporization of absorbed water, release of moisture and low molecular mass compounds such as extractives (French 2013; Karimi et al. 2014; Li et al. 2009). The second stage is the decomposition of hemicellulose, pectin and parts of lignin (between $150{ }^{\circ} \mathrm{C}$ and $310{ }^{\circ} \mathrm{C}$ ) with a $292{ }^{\circ} \mathrm{C}$ maximum degradation temperature (Silvério et al. 2013). The third stage, which occurs in the range of $310^{\circ} \mathrm{C}$ and $375^{\circ} \mathrm{C}$, with a $339^{\circ} \mathrm{C}$ maximum degradation temperature, occurred due to the loss weight promoted by cellulose decomposition, through reactions of depolymerization, dehydration and decomposition of glycoside units (Silvério et al. 2013).

The degradation of lignin also occurs simultaneously with other degradation stages and may still remain as a residue at the end of analysis, ranging from room temperature to $550{ }^{\circ} \mathrm{C}$. This occurs due to lignin having a complex structure and being composed of aromatic rings with various branches (Fioreet al. 2014; Mwaikambo and Ansell 2001; Teodoro et al. 2011). In the last stage, a shoulder peak near to $400{ }^{\circ} \mathrm{C}$ is related to the decomposition process, which involves simultaneous chemical reactions, such as the breaking of lignin $\mathrm{C}-\mathrm{C}$ bonds, dehydration, yielding derivatives with lateral unsaturated chains and water, $\mathrm{CO}_{2}, \mathrm{CO}$ and methane release (Spinacé et al. 2009). The general trend of the IB fiber is in accordance to other fibers found on literature (Karimi et al. 2014; Li et al. 2009; Morán et al. 2008; Normand et al. 2014; Sheltami et al. 2012) which were successfully used to nanocellulose obtention.

The amount of weight loss in each stage is also indicated in Table 3. The high weight loss (32.8\%) occurring in the third stage is related to the degradation of cellulose, because it is the larger component of fiber structure, and it is in accordance with the amount of cellulose determined in the chemical composition analysis

The amount of residue remaining at $550{ }^{\circ} \mathrm{C}$, due to the presence of carbonaceous materials according to Alemdar and Sain (2008), is almost the same value observed for that of soy hulls (Alemdar and Sain 2008), wheat straw (Alemdar and Sain 2008) and rice husk (Rosa et al. 2012) fibers and does not interfere in the extraction of nanocellulose as observed in the study of Alemdar and Sain (2008) and Rosa et al. (2012).

\section{FTIR analysis}

The FTIR spectrum of IB fibers shown in Figure 5, allows two main absorption regions, in the range of $3800-2600 \mathrm{~cm}^{-1}$ (Figure 5a) and between 2000 to $600 \mathrm{~cm}^{-1}$ (Figure 5b) to be distinguished and highlighted. These regions are the wavelengths where the main interactions between radiation and functional groups occur (Mandal and Chakrabarty 2011).

The broad and intense peak at $3311 \mathrm{~cm}^{-1}$ corresponds to an ansymmetric vibration of the free $\mathrm{O}-\mathrm{H}$ groups present in the cellulose $\mathrm{I}$ and $\mathrm{OH}$ groups that correspond to the intra-and intermolecular hydrogen bonds (Kargarzadeh et al. 2012; Kondo 1997; Mandal and Chakrabart 2011; Sheltami et al. 2012).

The two bands at 2917 and $2845 \mathrm{~cm}^{-1}$ are attributed to the asymmetric stretching of C-H group present in cellulose and hemicellulose and $\mathrm{C}=\mathrm{C}$ stretching from the aromatic ring of lignin (Jonoobi et al. 2009; Kasyapiet al. 2013; Sheltami et al. 2012).

A small band located at $1735 \mathrm{~cm}^{-1}$ was assigned to the $\mathrm{C}=\mathrm{O}$ stretching of the acetyl and uronic ester groups of hemicellulose or to the ester linkage of carboxylic group in the ferulic and p-coumaric acids of lignin and/or hemicellulose (Kargarzadeh et al. 2012; Jonoobi et al. 2009;

Table 3. Parameters from XRD analysis for IB fibers.

\begin{tabular}{lrrr}
\hline Properties & $(1-10)$ & $(110)$ & $(200)$ \\
\hline $2 \theta$ (degree) & 14.96 & 16.06 & 22.02 \\
d-spacing $(\mathrm{nm})$ & 0.59 & 0.55 & 0.40 \\
$L(\mathrm{~nm})$ & 8.30 & 5.52 & 3.23 \\
$\mathrm{Cl}(\%)$ & 36.60 & & \\
\hline
\end{tabular}




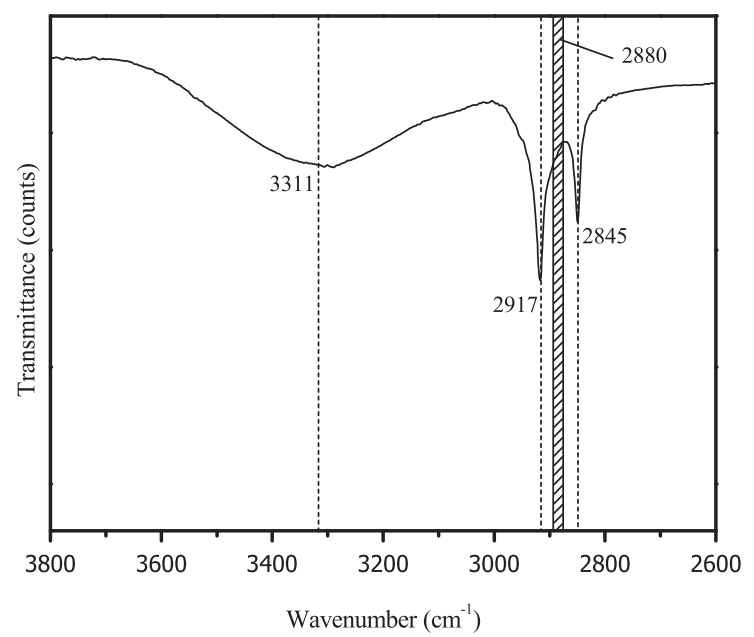

(a)

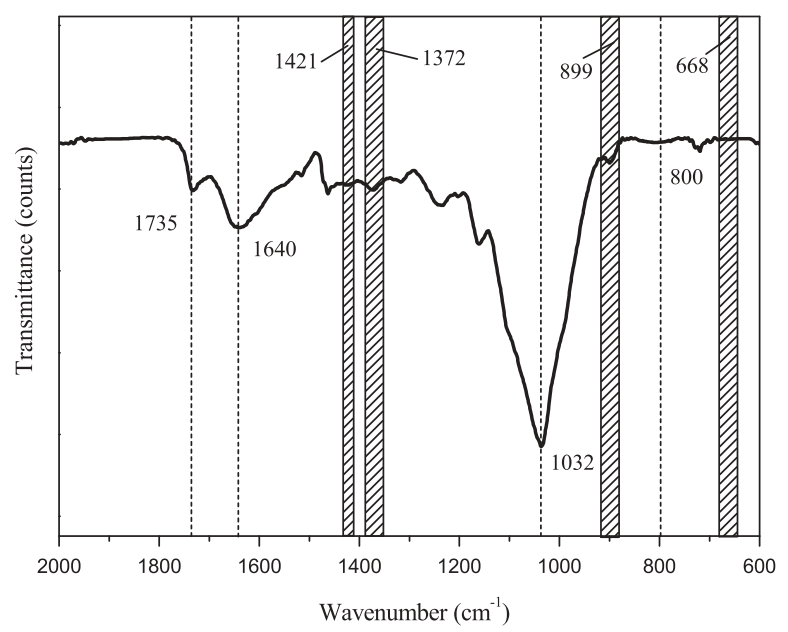

(b)

Figure 5. FTIR spectra of IB fibers.

Mandal and Chakrabarty 2011; Sheltami et al. 2012). The smaller peaks may be indicative of lower percentage of hemicellulose, which is an interesting characteristic in regards to nanocellulose extraction (Alemdar and Sain 2008).

The absorbance peak at $1640 \mathrm{~cm}^{-1}$ corresponds to bending vibrations of the $\mathrm{OH}$ group of cellulose and adsorbed water (Elsaid et al. 2001; Kargarzadeh et al. 2012; Mwaikambo and Ansell 2001). The intense peak at $1032 \mathrm{~cm}^{-1}$ is due to the C-O-C (Mandal and Chakrabarty 2011; Rosa et al. 2012) and/or the C-O stretching and C-H rocking vibrations of the pyranose ring skeletal vibration (Kargarzadeh et al. 2012).

Finally, the peak at $800 \mathrm{~cm}^{-1}$ was assigned to -glicosidic bonds between glucose units of amorphous cellulose (French 2013; Mandal and Chakrabarty 2011). This same absorbance peak was observed for sugarcane bagasse fibers in the study of nanocellulose obtention of Mandal and Chakrabarty (2011).

The CI can be determined by FT-IR spectroscopy (see hatched areas in Figure 5) (Dai and Fan 2011). The ratios of absorbance at $1421 \mathrm{~cm}^{-1}$ and $899 \mathrm{~cm}^{-1}, 1372 \mathrm{~cm}^{-1}$ and $2880 \mathrm{~cm}^{-1}$ or $1372 \mathrm{~cm}^{-1}$ 
and $668 \mathrm{~cm}^{-1}$ can be used for evaluating IR crystallinity. In this study, the ratio of the absorption band $A_{1372} / A_{668}$ seems to be more suitable for evaluating with a CI of $45.39 \%$. The values obtained using the Segal method was $36.6 \%$. This difference is similar with the one obtained for Dai and Fan (2011) using the same method.

\section{$X$-ray analysis}

The deconvolution of the peaks, obtained from X-ray analysis, was initially performed to check the contribution of each crystal type in crystalline fiber properties. Points used in the deconvolution were determined according to the standard crystallographic cellulose $I_{\beta}$, which was inserted into the Mercury 3.0 software program from the Cambridge Crystallographic Data Centre (public domain) (French 2013), provided in its digital supplementary material. Figure 6 shows the simulated cellulose $\mathrm{I}_{\beta}$ powder pattern for crystallites with $1^{\circ}$ and $3^{\circ}$ peak width at half-maximum (pwhm) intensities, respectively.

Figure 7 shows the X-ray diffraction (XRD) pattern obtained for IB fibers. This pattern is typical of a semicrystalline material such as lignocellulosic materials that yield an amorphous broad hump and a crystalline peak upon analysis of their diffraction pattern (Guimarães et al. 2010).

One peak was observed at $2 \theta \approx 15^{\circ}$, which corresponds to the crystallographic overlapping planes $(110)$ and $(1-10)$. A peak at $2 \theta \approx 22^{\circ}$ is due to crystallographic planes (200) and another peak at $2 \theta \approx 35^{\circ}$ is associated to crystallographic planes (004) or (023), which are characteristic of the crystal polymorph $\mathrm{I}_{\beta}$ of cellulose.

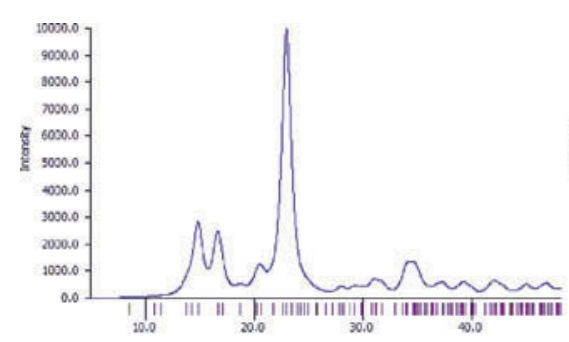

(a)

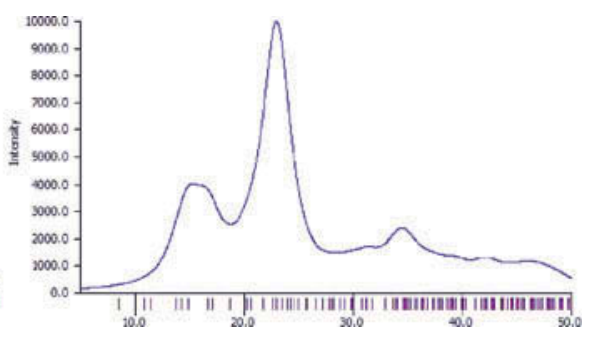

(b)

Figure 6. Crystallographic plane for cellulose $I_{\beta}$, from mercury program: (a) pwhm $=1$ and (b) pwhm $=3$.

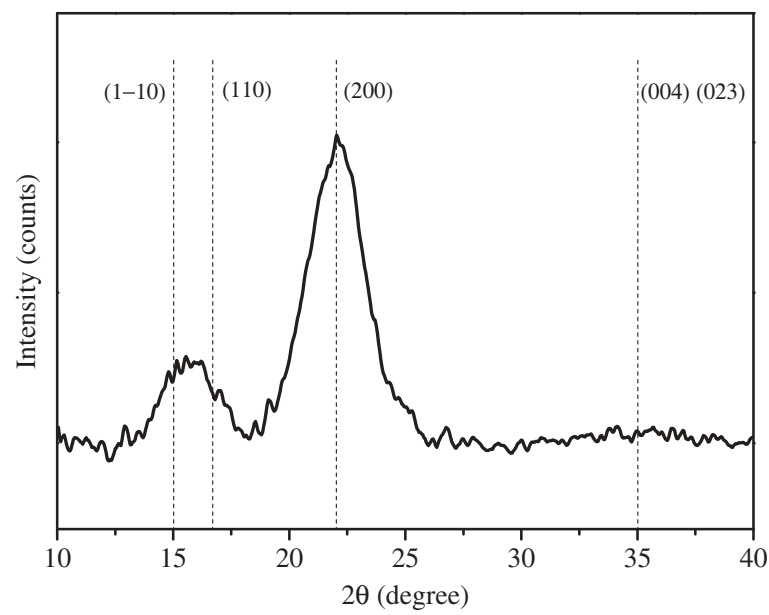

Figure 7. X-ray diffraction patterns of IB fibers. 
Two peaks near to $2 \theta \approx 15^{\circ}$ are more visible for lignocellulosic fibers with higher amounts of cellulose such as curaua, cotton and flax (Ornaghi Jr. et al. 2014b). For other lignocellulosic fibers, generally used for nanocellulose extraction, such as sugarcane bagasse (Mandal and Chakrabarty 2011), kenaf (Kargarzadeh et al. 2012; Jonoobi et al. 2009), sisal (Siqueira et al. 2010) and coconut (Abraham et al. 2013, Rosa et al. 2010), these two peaks are covered by amorphous constituents, mainly lignin, hemicellulose and amorphous cellulose, as observed for IB fibers (Spinacé et al. 2009).

The calculated CI value (36.6\%) is smaller than that of Cissus quadrangularis root (56.6\%) (Indran et al. 2014) however is almost the same as that of garlic skin (35\%) (Siqueira et al. 2010) which are also successfully used to extract nanocellulose fibers.

The crystallinity of cellulosic materials is not a obstacle in the nanocellulose obtention, but interferes in the final process yield, since as higher the CI, greater will be the amount of obtained nanocellulose. In addition is an important feature because it interferes with the practical performance characteristics of these materials as it affects other properties like thermal and mechanical ones (Ornaghi Jr. et al. 2014b, Alemdar and Sain 2008).

Within this context, other cellulose crystalline properties, for each crystallographic plane at (1-10), (110) and (200) of IB fibers were also calculated and shown in Table 3.

The values of d-spacing for the crystallographic plane (200) are the same of that reported by Ornaghi Jr. et al. (2014a) for curaua, jute and kenaf fibers. The crystallite size (L) values follow the order $(1-10)>(110)>(200)$. This value it is of great important because is a relationship between crystallite size and the pattern that are recorded by diffraction analysis (which can be measured by Scherrer equation) since different cellulosic materials has different and varying crystallite sizes which reflects in some of their properties (French and Santiago Cintrón 2013).

Then in comparison with other lignocellulosic fibers, IB fibers present a higher crystalline size than of jute $(2.94 \mathrm{~nm})$ and kenaf fibers $(2.71 \mathrm{~nm}$ ) (Ornaghi Jr. et al. 2014a) and a crystalline size smaller than that of Cissus quadrangularis root $(28.05 \mathrm{~nm}$ ) (Indran et al. 2014) and curaua fibers $(3.42 \mathrm{~nm})$ (Ornaghi Jr. et al. 2014a). The higher crystal size structure leads to lower water absorption and a decreasing crystallite on the surface corresponding to the amorphous phase (French 2013; Indran et al. 2014).

\section{Conclusions}

Brazilian Satintail fibers extracted from the Imperata brasiliensis plant, which is commonly considereda weed in plantations of Brazil, were studied. Several properties were analyzed to determine the main characteristics of this new lignocellulosic source, as a promising agricultural residue, for nanocellulose fibers extraction. In general, any lignocellulosic fiber can be used for the extraction of nanocellulose, but one of the most important parameters to be considered is the amount of cellulose, since that, during the extraction process, other components (mainly lignin and hemicelluloses) are removed.

Analyzing the results of chemical composition, it was observed that cellulose content of the IB fiber is an acceptable value when compared with other fibers, which were also used in nanocellulose extraction and showed satisfactory results.

With other characterizations (SEM, TGA, FTIR and XRD) besides to confirm the results obtained in the analysis of chemical composition, it was possible to found the similarity of the IB properties with other fibers cited in the literature as good sources of nanocellulose extraction. In addition, analyzing the results of XRD and FTIR it was observed a crystallinity content of approximately $40 \%$, that is closely associated with the presence of crystalline cellulose, while the other fiber components are amorphous.

Finally, whereas IB fibers have similar properties to other lignocellulosic fibers successfully used to obtain nanocellulose, as reported in literature, it is possible to consider, based on the results presented, that this plant is a promising source for nanocellulose extraction, thus adding value to the raw material from a renewable source. 


\section{Funding}

The authors acknowledge FAPESP through process 2011/14153-8, PNPD/CAPES and CAPES for fellowships and financial support.

\section{ORCID}

Kelly Cristina Coelho de Carvalho Benini (iD http://orcid.org/0000-0003-2912-3752

\section{References}

Abe, K., and H.Yano. 2009. Comparison of the characteristics of cellulose microfibril aggregates of wood, rice straw and potato tuber. Cellulose 16: 1017-1023. doi:10.1007/s10570-009-9334-9.

Abraham, E., B. Deepa, L. A. Pothen, J. Cintil, S. Thomas, M. J. John, and S. S. Narine. 2013. Environmental friendly method for the extraction of coir fibre and isolation of nanofibre. Carbohydrate Polymers 92:1477-1483. doi:10.1016/j.carbpol.2012.10.056.

Alemdar, A., and M. Sain. 2008. Isolation and characterization of nanofibers from agricultural residues-Wheat straw and soy hulls. Bioresource Technology 99:1664-1671. doi:10.1016/j.biortech.2007.04.029.

Beg, M. D. H., and K. L. Pickerin. 2008. Accelerated weathering of unbleaching and bleached kraft wood fibre reinforced polypropylene composites. Polymer Degradation and Stability 93: 1939-1946. doi:10.1016/j. polymdegradstab.2008.06.012.

Belbekhouche, S., J. Bras, G. Siqueira, C. Chappey, L. Lebrun, B. Khelifi, and A. Dufresne. 2011. Water sorption behavior and gas barrier properties of cellulose whiskers and microfibrils films. Carbohydrate Polymers 83:1740-1748. doi:10.1016/j.carbpol.2010.10.036.

Bilba, K., M.-A. Arsene, and A. Ouensanga. 2007. Study of banana and coconut fibers botanical composition, thermal degradation and textural observations. Bioresource Technology 98:58-68. doi:10.1016/j.biortech.2005.11.030.

Carvalho, M. M., D. F. Xavier, V. D. P. Freitas, and R. Silva. 2000. Correção da Acidez do Solo e Controle do Capim-Sapé. Revista Brasileira De Zootecnia 29: 33-39. doi:10.1590/S1516-35982000000100005.

Chen, W., H. Yu, Y. Liu, Y. Hai, M. Zhang, and P. Chen. 2011. Isolation and characterization of cellulose nanofibers from four plant cellulose fibers using a chemical-ultrasonic process. Cellulose 18: $433-442$. doi:10.1007/s10570-011-9497-z.

Dai, D., and M. Fan. 2011. Investigation of the dislocation of natural fibres by Fourier-transform infrared spectroscopy. Vibrational Spectroscopy 55: 300-306. doi:10.1016/j.vibspec.2010.12.009.

Dufresne, A. 2000. Cellulose microfibrils from potato tuber cells: Processing and characterization of starch-cellulose microfibril composites. Polymer 76: 2080-2092.

Elsaid, A., M. Dawood, R. Seracino, and C. Bobko. 2001. Mechanical properties of kenaf fiber reinforced concrete. Construction and Building Materials 25: 1991-2001. doi:10.1016/j.conbuildmat.2010.11.052.

Fiore, V., T. Scalici, and A. Valenza. 2014. Characterization of a new natural fiber from Arundo donax L. as potential reinforcement of polymer composites. Carbohydrate Polymers 106: 77-83. doi:10.1016/j.carbpol.2014.02.016.

French, A. D. 2013. Idealized powder diffraction patterns for cellulose polymorphs. Cellulose 21:885-896. doi:10.1007/ s10570-013-0030-4

French, A. D., and M. Santiago Cintrón. 2013. Cellulose polymorphy, crystallite size, and the segal crystallinity index. Cellulose 20:583-588. doi:10.1007/s10570-012-9833-y.

Guimarães, J. L., F. Wypych, C. K. Saul, L. P. Ramos, and K. G. Satyanarayana. 2010. Studies of the processing and characterization of corn starch and its composites with banana and sugarcane fibers from Brazil. Carbohydrate Polymers 80: 130-138. doi:10.1016/j.carbpol.2009.11.002.

Howard, J. L. 2005. Imperata brasiliensis, I. cylindrica. In: Fire Effects Information System, [Online]. U.S. Department of Agriculture, Forest Service, Rocky Mountain Research Station, Fire Sciences Laboratory (Producer). http://www. fs.fed.us/database/feis/. (Accessed September 5, 2014).

Indran, S., R. E. Raj, and V. S. Sreenivasan. 2014. Characterization of new natural cellulosic fiber from Cissus quadrangularis root. Carbohydrate Polymers 110: 423-429. doi:10.1016/j.carbpol.2014.04.051.

John, M. J., and S. Thomas. 2008. Biofibres and biocomposites. Carbohydrate Polymers 71: 434-464.

Jonoobi, M., J. Harun, A. Shakeri, and M. Misra. 2009. Chemical composition, crystallinity, and thermal degradation of bleached and unbleached kenaf bast (Hibiscus cannabinus) pulp and nanofibers. BioResources 4: 626-639.

Jonoobi, M., A. Khazaeian, P. M. Tahir, S. S. Azry, K. Oksman. 2011. Characteristics of cellulose nanofibers isolated from rubberwood and empty fruit bunches of oil palm using chemo-mechanical process. Cellulose 1085-1095. doi:10.1007/s10570-011-9546-7

Kargarzadeh, H., I. Ahmad, I. Abdullah, A. Dufresne, S. Y. Zainudin, and R. M. Sheltami. 2012. Effects of hydrolysis conditions on the morphology, crystallinity, and thermal stability of cellulose nanocrystals extracted from kenaf bast fibers. Cellulose 19: 855-866. doi:10.1007/s10570-012-9684-6. 
Karimi, S., P. M. Tahir, A. Karimi, A. Dufresne, and A. Abdulkhani. 2014. Kenaf bast cellulosic fibers hierarchy: A comprehensive approach from micro to nano. Carbohydrate Polymers 101: 878-885. doi:10.1016/j.carbpol.2013.09.106.

Kasyapi, N., V. Chaudhary, and A. K. Bhowmick. 2013. Bionanowhiskers from jute: Preparation and characterization. Carbohydrate Polymers 92: 1116-1123. doi:10.1016/j.carbpol.2012.10.021.

Kondo, T. 1997. The assignment of IR absorption bands due to free hydroxyl groups in cellulose. Cellulose 4: 281-292. doi:10.1023/A:1018448109214.

Lee, H. V., S. B. A. Hamid, and S. K. Zain. 2014. Conversion of lignocellulosic biomass to nanocellulose: Structure and chemical process. The Scientific World Journal 2014: 1-20.

Li, R., J. Fei, Y. Cai, Y. Li, J. Feng, and J. Yao. 2009. Cellulose whiskers extracted from mulberry: A novel biomass production. Carbohydrate Polymers 76: 94-99. doi:10.1016/j.carbpol.2008.09.034.

Machado, M. S., C. E. Sato, D. R. Mulinari, M. O. H. Cioffi, and H. J. C. Voorwald. 2009. Avaliação térmica do tratamento alcalino em naturais. Anais do $10^{\circ}$ Congresso brasileiro de Polímeros - CBPol, Foz do Iguaçu-PR.

Mandal, A., and D. Chakrabarty. 2011. Isolation of nanocellulose from waste sugarcane bagasse (SCB) and its characterization. Carbohydrate Polymers 86:1291-1299. doi: 10.1016/j.carbpol.2011.06.030.

Mariño, M., L. L.Silva, N. Durán, and L. Tasic. 2015. Enhanced materials from nature: nanocellulose from citrus waste. Molecules 20: 5908-5923.

Methacanon, P., U. Weerawatsophon, N. Sumransin, C. Prahsarn, D. T. Bergado. 2010. Properties and potential application of the selected natural fibers aslimited life geotextiles. Carbohydrate Polymers 82: 1090-1096.

Morais, J. P. S., M. F. Rosa, M. M. Souza Filho, L. D. Nascimento, D. M. Nascimento, and A. R. Cassales. 2013. Extraction and characterization of nanocellulose structures from raw cotton linter. Carbohydrate Polymers 91:229-235. doi:10.1016/j.carbpol.2012.08.010.

Morán, J. I., V. A. Alvarez, V. P. Cyras, and A. Vázquez. 2008. Extraction of cellulose and preparation of nanocellulose from sisal fiber. Cellulose 15: 149-159. doi:10.1007/s10570-007-9145-9.

Mulinari, D. R., M. O. H. Cioffi, and H. J. C. Voorwald. 2009. Review on natural fibers /HDPE composites: Effect of chemical modification on the mechanical and thermal properties. In Green composites: Properties, design and life cycle assessment, eds. F. Willems and P. Moens, 53-78. New York, USA: Nova Science Publishers Inc.

Mwaikambo, L. Y., and M. P. Ansell. 2001. The determination of porosity and cellulose content of plant fibers by density methods. Journal of Materials Science and Letters 20: 2095-2096. doi:10.1023/A:1013703809964.

Ng, H.-M., L. T.Sin, -T.-T.Tee, S.-T. Bee, D.Hui, C.-Y.Low, and A. R.Rahmat. 2015. Extraction of cellulose nanocrystals from plant sources for application as reinforcing agent in polymers. Composites-Part B 75: 176-200. doi:10.1016/j.compositesb.2015.01.008.

Normand, M. L., R. Moriana, and M. Ek. 2014. Isolation and characterization of cellulose nanocrystals from spruce bark in a biorefinery perspective. Carbohydrate Polymers 111: 979-987. doi:10.1016/j.carbpol.2014.04.092.

Ornaghi, H. L., Jr., M. Poletto, A. J. Zattera, and S. C. Amico. 2014b. Correlations of the thermal stability and the decomposition kinetics of six different vegetal fibers. Cellulose 21:177-188b. doi:10.1007/s10570-013-0094-1.

Ornaghi, H. L., Jr., A. J. Zattera, and S. C. Amico. 2014a. Thermal behavior and the compensation effect of vegetal fibers. Cellulose 21:189-201a. doi:10.1007/s10570-013-0126-x.

Pereira, P. H. F., M. F. Rosa, M. O. H. Cioffi, K. C. C. C. Benini, A. C. Milanese, H. J. C. Voorwald, and D. R. Mulinari. 2015. Vegetal fibers in polymeric composites: A review. Polímeros 25: 9-22. doi:10.1590/0104-1428.1722.

Poletto, M., A. J. Zattera, M. M. C. Forte, and R. M. C. Santana. 2012. Thermal decomposition of wood: Influence of wood components and cellulose crystallite size. Bioresource and Technology 109: 148-153. doi:10.1016/j. biortech.2011.11.122.

Poletto, M., A. J. Zattera, and R. M. C. Santana. 2012. Structural differences between wood species: Evidence from chemical composition, FTIR spectroscopy, and thermogravimetric analysis. Journal of Applied Polymer Science 126: E337-E344. doi:10.1002/app.36991.

Reddy, J. P., and J. W. Rhim. 2014. Isolation and characterization of cellulose nanocrystals from garlic skin. Materials Letters 129: 20-23. doi:10.1016/j.matlet.2014.05.019.

Reddy, N., and Y. Yang. 2008. Characterizing natural cellulose fibers from velvet leaf (Abutilon theophrasti) stems. Bioresource Technology 99: 2449-2454. doi:10.1016/j.biortech.2007.04.065.

Romanzini, D., H. L.OrnaghiJr., S. C.Amico, and A. J.Zattera. 2012. Preparation and characterization of ramie-glass fiber reinforced polymer matrix hybrid composites. Materials Research 15: 415-420. doi:10.1590/S1516-14392012005000050.

Rosa, M. F., E. S. Medeiros, J. A. Malmonge, K. S. Gregorski, D. F. Wood, L. H. C. Mattoso, S. H. Imam. 2010. Cellulose nanowhiskers from coconut husk fibers: Effect of preparation conditions on their thermal and morphological behavior. Carbohydrate Polymers 83-92. doi:10.1016/j.carbpol.2010.01.059

Rosa, S. M. L., N. Rehman, M. I. G. De Miranda, S. M. B. Nachtigall, and C. I. D. Bica. 2012. Chlorine-free extraction of cellulose from rice husk and whisker isolation. Carbohydrate Polymers 87: 1131-1138. doi:10.1016/j. carbpol.2011.08.084.

Segal, L., J. J. Creely, A. E. Martin Jr., and C. M. Conrada. 1959. An empirical method for estimating the degree crystallinity of native cellulose using the X-ray diffractometer. Textile Research Journal 786-794. doi:10.1177/ 004051755902901003. 
Sheltami, R. M., I. Abdullah, I. Ahmad, A. Dufresne, and H. Kargarzadeh. 2012. Extraction of cellulose nanocrystals from mengkuang leaves (Pandanus tectorius). Carbohydrate Polymers 88: 772-779. doi:10.1016/j.carbpol.2012.01.062.

Silva, S. S., R. R. Carvalho, J. L. C. Fonseca, and R. B. Garcia. 1998. Extração e caracterização de xilanas de sabugo de milho. Polímeros 8: 25-33. doi:10.1590/S0104-14281998000200005.

Silvério, H. A., W. P. Flauzino Neto, N. O. Dantas, and D. Pasquini. 2013. Extraction and characterization of cellulose nanocrystals from corncob for application as reinforcing agent in nanocomposites. Industrial Crops and Products 44:427-436. doi:10.1016/j.indcrop.2012.10.014.

Siqueira, G., H. Abdillahi, J. Bras, and A. Dufresne. 2010. High reinforcing capability cellulose nanocrystals extracted from Syngonanthus nitens (Capim Dourado). Cellulose 17: 289-298. doi:10.1007/s10570-009-9384-z.

Souza, R. M., N. M. Teixeira, and R. A. Torres. 1985. Métodos de controle do sapê em pastagem de capim-gordura. Pesquisa Agropecuária Brasileira 20:963-967.

Spinacé, M. A. S., C. S. Lambert, K. K. G. Fermoselli, and M. A. De Paoli. 2009. Characterization of lignocellulosic curaua fibres. Carbohydrate Polymers 77: 47-53. doi:10.1016/j.carbpol.2008.12.005.

Teixeira, E. M., A. C. Corrêa, A. Manzoli, F. L. Leite, C. R. Oliveira, and L. H. C. Mattoso. 2010. Cellulose nanofibers from white and naturally colored cotton fibers. Cellulose 17:595-606. doi:10.1007/s10570-010-9403-0.

Teodoro, K. B. R., E. M. Teixeira, A. C. Corrêa, A. Campos, J. M. Marconcini, and L. H. C. Mattoso. 2011. Whiskers from sisal fibers obtained under under different acid hydrolysis conditions: Effect of time and temperature of extraction. Polímeros 21: 280-285. doi:10.1590/S0104-14282011005000048.

USDA - United States Department of Agriculture. 2014. ARS-Agricultural Research Service, National Genetc Resources Program. http://www.ars-grin.gov/cgi-bin/npgs/html/family.pl?2479 (Accessed September 5, 2014). 